\title{
EFFECTIVENESS OF PROGRESSIVE MUSCLE RELAXATION TECHNIQUE ON ANXIETY AMONG ELDERLY
}

\author{
G S Tak ${ }^{1}$, S K Maheshwari ${ }^{2 *}$, Manpreet Kaur ${ }^{3}$ \\ ${ }^{1}$ State Institute of Nursing \& Paramedical Sciences, Badal, Punjab, India \\ ${ }^{2}$ University College of Nursing, BFUHS, Faridkot, Punjab, India \\ ${ }^{3}$ Baba Moni Ji Maharaj College of Nursing, Bathinda, Punjab, India
}

\begin{abstract}
Introduction: Old age is characterized by certain physical and psychological changes and is associated with high level of anxiety. Literature reports that $11 \%$ of elderly are suffering from anxiety and anxiety disorders. Progressive muscle relaxation technique is very effective in reducing anxiety.

Aim: The aim of study is to assess the effectiveness of progressive muscle relaxation technique on anxiety among elderly residing in selected old age homes.

Methodology: Quasi-experimental research design under quantitative research approach was used to conduct study. Sixty participants (thirty in experimental and thirty in control group) were selected through convenience sampling technique for study. Data was collected through interview method using socio-demographic profile Hamilton Anxiety Rating scale .Progressive muscle relaxation technique has been demonstrated and intervention continued for once a day for 7 days for 20-30 minutes daily to the experimental group after pretest.

Results: Findings of study revealed that In experimental group $46.7 \%, 43.3 \%$, had moderate, severe anxiety respectively and in control group $36.7 \%, 46.7 \%$ had moderate and severe anxiety respectively before intervention and after intervention in experimental group anxiety had reduced mild (36.7\%) and moderate (46.7\%) and in control group $40 \%$ had moderate and severe anxiety. There is a significant difference in pre and post test level of anxiety in the experimental group. The level of anxiety is found to be associated with gender at $\mathrm{p}<0.05$.
\end{abstract}

Conclusion: Study concluded that progressive muscle relaxation is effective in reducing the level of anxiety among elderly but need to conduct the same study on a large sample.

Keywords: effectiveness, anxiety, progressive muscle relaxation technique, elderly and old age homes.

\section{INTRODUCTION}

Old age is the closing period in the life span. It is a period when people "move away" from previous, more desirable period of times of "usefulness". Like every other period in life span old age is characterized by certain physical and psychological changes. The effect of these changes to determines, to a large extent whether elderly men and women will make good or poor personal and social adjustments. ${ }^{1}$

Most anxiety disorders begin in early to middle adulthood, but some appear for the first time after age 60 . The fragility of the autonomic nervous system in older persons may account for the development of anxiety after a major stressor. ${ }^{2}$ Aging is not a risk factor for anxiety but rather a protective one. However, several biological, psychological, and social risk factors for anxiety disorders have been identified for older adults. ${ }^{3}$

*Corresponding author:

Email: skmbfuhs@gmail.com

http://dx.doi.org/10.20530/IJTA $32 \quad 48-54$

ISSN 2320-138X (c) 2016
Among elderly anxiety is a major health problem. Anxiety disorder such as panic disorder, phobia, obsessive and compulsive disorder and somatoform disorders occur more than $4 \%$ of the elderly population. Studies have shown generalized anxiety disorder is more common in the elderly, affecting $7 \%$ of the seniors. ${ }^{4}$

According to United Nations population fund (UNFPA), 1 out of every 10 persons is now 60 years or older. The elderly population will increase to $12 \%$ of the total population by $2025,10 \%$ of whom would be bedridden, requiring utmost care. Latest census (2011) of India revealed that more than 76 million people aged 60 years and over. This age group currently constitutes $7.4 \%$ of the Indian population. ${ }^{4}$ Facts of elderly shows that India has $2^{\text {nd }}$ largest elderly $(+60)$ population in the world. ${ }^{5}$

The survey was conducted in Karnataka had shown that the incidence of anxiety related disease was alarmingly increasing among elderly due to separation from children's, death of the spouse and physical changes. The survey has shown that $49 \%$ of elderly will have some form of anxiety disorders which will lead to the development of depressive disorders in 
future. ${ }^{6}$ Anxiety and anxiety disorders are common in the elderly, in part due to concerns and worries about bodily symptoms and changes in health. Some of this are related to the fear of death and dying. ${ }^{7}$

A study conducted on evidence-based commentary to assess status and requirements of geriatric mental health services in India. Data indicated an average of $20.5 \%$ mental health morbidity in older adults. Accordingly, it was found that, at present, 17.13 million older adults (total population, 83.58 million) are suffering from mental health problems in India. There is an urgent need to develop the subject and geriatric mental health care services in India. ${ }^{8}$

Generally speaking, the elderly live a lonely life and face health problems; isolation, reduced a sense of purpose in life, worries, anxiety, and fear may all lead to major mental health problems. So the researcher recognizes the importance to support the positive and active living of the elderly because there is lacking of the provision of psychological health services in the geriatric area of nursing.

\section{MATERIAL AND METHODS:}

The present study was conducted through quasi-experimental non-randomized control group design under quantitative research approach in selected old age homes of Punjab. The old age homes were selected on the basis of availability of elderly, giving permission to conduct the study and convenience in terms of distance.

Sample was selected by non-probability convenience sampling technique. Sample size taken was 60 (30 in the experimental group and 30 in the control group). Progressive muscle relaxation technique was independent, and level of anxiety was the dependent variable. Ethical approval to conduct the study was taken from the College and University. Administrative approval was taken from concerned authorities of old age homes. The consent form was prepared for the study subjects regarding their willingness to participate in the research project. The research tool for data collection consists of two sections:

Tool 1: Socio- demographic profile: It consists of items seeking information pertaining to the selected variables of subject like age ,gender, residence, religion, educational status, marital status, occupation before joined to old age home, source of income, reason for staying in the old age home, and length of stay in old age home. Content validity of tool was determined by experts in the field of psychiatry, psychiatric nursing, and psychology respectively. Content appropriateness, clarity, and relevance were ascertained by the language expert.

Tool 2: Hamilton Anxiety Rating scale (HAM-A): It was selected to assess pre-test and post test level of anxiety among elderly. This scale was given by Hamilton, (1959) which was applied to evaluate anxiety in order to quantify its severity. It consists of 14 items which is defined by a series of symptoms and measures both psychic anxiety and somatic anxiety. Each item is rated on a 5-point scale ranging from $0-4$ and its minimum score is 0 and maximum score is 56 . The administration time for scale is 10-15 minutes. The Hamilton Anxiety Rating Scale was standardized questionnaire having internal consistency alpha $=0.77$ to 0.92 . Score $0-13$ was considered as no anxiety, 14-17 as mild anxiety, 18-24 as moderate anxiety and $\geq 25$ as severe anxiety. The Hamilton Anxiety Rating Scale is standardized questionnaire having internal consistency alpha $=0.77$ to 0.92 . Reliability was checked through test - retest method and reliability coefficient was found to be 0.9 . Thus the tool was found to be highly reliable. Content validity of tools was ensured by submitting to the experts in the field of mental health and language experts in English and Punjabi.

The intervention (progressive muscle relaxation technique) was procured from the books, internet source, and discussion with a psychologist, supervisor and co-supervisor. The duration of the demonstration was 40 minutes.

Sample was selected through convenience sampling technique. Sixty subjects were selected (thirty in experimental and in the control group, each). Pre-test of experimental group, as well as a control group, was conducted by using interview method after obtaining the consent and the duration of an interview was 15-20 minutes for each subject. Progressive muscle relaxation technique was administered to the experimental group only by demonstration method within 45 minutes and continued practicing intervention session for 20-30 minutes for 7 days once in a day (in groups having 6 subjects in each group). Posttest data was collected on $8^{\text {th }}$ day from both the groups. Statistical analysis was done through differential and inferential statistics using SPSS 18 and level of significance $<0.05$ was considered as significant.

\section{RESULTS}

Table 1 reveals the baseline comparison of subjects as per their socio-demographic character - 
Table 1: Frequency and percentage distribution of socio-demographic variables of sample and basement comparison of experimental and control group.

\begin{tabular}{|c|c|c|c|c|c|c|}
\hline \multirow{3}{*}{ Demographic variables } & \multirow{2}{*}{\multicolumn{2}{|c|}{$\begin{array}{l}\text { Experimental group } \\
(n=30)\end{array}$}} & \multirow{2}{*}{\multicolumn{2}{|c|}{$\begin{array}{c}\text { Control group } \\
(n=30)\end{array}$}} & \multirow{3}{*}{$\begin{array}{l}\text { Chi } \\
\text { Square } \\
\text { Df }\end{array}$} & \multirow{3}{*}{$\begin{array}{r}\mathrm{N}=60 \\
P \text { value }\end{array}$} \\
\hline & & & & & & \\
\hline & (f) & $(\%)$ & (f) & $(\%)$ & & \\
\hline \multicolumn{7}{|l|}{ Age (years): } \\
\hline $60-65$ & 10 & 33.3 & 8 & 26.7 & 1.785 & $0.61^{\mathrm{NS}}$ \\
\hline $66-70$ & 9 & 30.0 & 13 & 43.3 & $\mathrm{Df}=3$ & \\
\hline 71-75 & 8 & 26.7 & 5 & 16.7 & & \\
\hline$>75$ & 3 & 10.0 & 4 & 13.3 & & \\
\hline \multicolumn{7}{|l|}{ Gender: } \\
\hline Male & 21 & 70.0 & 17 & 56.7 & 1.148 & $0.28^{\mathrm{NS}}$ \\
\hline Female & 9 & 30.0 & 13 & 43.3 & $D f=1$ & \\
\hline \multicolumn{7}{|l|}{ Residence : } \\
\hline Rural & 22 & 73.3 & 13 & 43.3 & 5.554 & $0.018^{* *}$ \\
\hline Urban & 8 & 26.7 & 17 & 56.7 & $D f=1$ & \\
\hline \multicolumn{7}{|l|}{ Religion: } \\
\hline Sikh & 23 & 76.7 & 23 & 76.7 & 1.077 & $0.584^{\mathrm{NS}}$ \\
\hline Hindu & 6 & 20.0 & 7 & 23.3 & $\mathrm{Df}=2$ & \\
\hline Muslim & 1 & 3.3 & 0 & 0 & & \\
\hline \multicolumn{7}{|l|}{ Educational status: } \\
\hline Illiterate & & & & & & $0.348^{\mathrm{NS}}$ \\
\hline Below middle & 15 & 50.0 & 12 & 40.0 & 3.299 & \\
\hline Below senior secondary & 7 & 23.3 & 11 & 36.7 & $D f=3$ & \\
\hline \multirow[t]{2}{*}{ Graduate } & 6 & 20.0 & 7 & 23.3 & & \\
\hline & 2 & 6.7 & 0 & 0 & & \\
\hline \multicolumn{7}{|l|}{ Marital status: } \\
\hline Single & 7 & 23.3 & 9 & 30.0 & 5.635 & $0.131^{\text {NS }}$ \\
\hline Married & 12 & 40.0 & 4 & 13.3 & $D f=3$ & \\
\hline Widow/ widower & 10 & 33.3 & 16 & 53.3 & & \\
\hline Divorced & 1 & 3.3 & 1 & 3.3 & & \\
\hline \multicolumn{7}{|c|}{ Occupation before joined to old age home } \\
\hline Government employee & 2 & 6.7 & 1 & 3.3 & & \\
\hline Private employee & 5 & 16.7 & 4 & 13.3 & 1.326 & $0.723^{\mathrm{NS}}$ \\
\hline House wife & 9 & 30.0 & 13 & 43.3 & $D f=3$ & \\
\hline Farmer/laborer & 14 & 46.7 & 12 & 40.0 & & \\
\hline \multicolumn{7}{|l|}{ Source of income } \\
\hline Pensioner & 11 & 36.7 & 7 & 23.3 & 8.984 & $0.01 * *$ \\
\hline Support from family/ others & 5 & 16.7 & 16 & 53.3 & $D f=2$ & \\
\hline None & 14 & 46.7 & 7 & 23.3 & & \\
\hline \multicolumn{7}{|l|}{ Reason for staying in old age home } \\
\hline No family members/ relatives & 7 & 23.3 & 10 & 33.3 & 8.719 & $0.01 * *$ \\
\hline Neglected from children /family & 23 & 76.7 & 14 & 46.7 & $D f=2$ & \\
\hline Poverty & 0 & 0 & 6 & 20.0 & & \\
\hline \multicolumn{7}{|l|}{ Length of stay in old age home } \\
\hline Up to 2 years & 21 & 70.0 & 13 & 43.3 & $7.082^{\mathrm{NS}}$ & $0.069^{\mathrm{NS}}$ \\
\hline 2- 5years & 6 & 20.0 & 9 & 30.0 & $D f=3$ & \\
\hline More than 5 years & 3 & 10.0 & 8 & 26.7 & & \\
\hline
\end{tabular}

*S- significant, NS - non significant

istics in experimental and control group.

In age wise distribution in experimental group, the table reveals that majority of them 10 (33.3\%) were in age group of 60-65 years, whereas in control group majority of elderly $13(43.3 \%)$ were in age group of 66-70 years

In gender wise distribution that majority of elderly $21(70 \%)$ and $17(56.7 \%)$ were male in 
Table 2: Assessment of frequency, percentage distribution, and comparison of the pre-test and post test level of anxiety among elderly in experimental group and control group

\begin{tabular}{|c|c|c|c|c|c|c|c|c|c|}
\hline & & & & & & & & & $(\mathrm{N}=60)$ \\
\hline \multirow[t]{2}{*}{ GROUP } & \multicolumn{4}{|c|}{ PRE TEST ANXIETY } & \multicolumn{4}{|c|}{ POST TEST ANXIETY } & \multirow[t]{2}{*}{$(x 2) \mathrm{df}$} \\
\hline & $\begin{array}{c}\text { No } \\
\text { anxiety }\end{array}$ & $\begin{array}{c}\text { Mild } \\
\text { anxiety }\end{array}$ & $\begin{array}{l}\text { Moderate } \\
\text { anxiety }\end{array}$ & $\begin{array}{l}\text { Severe } \\
\text { anxiety }\end{array}$ & $\begin{array}{c}\text { No } \\
\text { anxiety }\end{array}$ & $\begin{array}{c}\text { Mild } \\
\text { anxiety }\end{array}$ & $\begin{array}{l}\text { Moderate } \\
\text { anxiety }\end{array}$ & $\begin{array}{l}\text { Severe } \\
\text { anxiety }\end{array}$ & \\
\hline $\begin{array}{l}\text { Experimental } \\
n=30(\%)\end{array}$ & $\begin{array}{c}2 \\
(6.7)\end{array}$ & $\begin{array}{c}1 \\
(3.3)\end{array}$ & $\begin{array}{c}14 \\
(46.7)\end{array}$ & $\begin{array}{c}13 \\
(43.3)\end{array}$ & $\begin{array}{c}5 \\
(16.7)\end{array}$ & $\begin{array}{c}11 \\
(36.7)\end{array}$ & $\begin{array}{c}14 \\
(46.7)\end{array}$ & $\begin{array}{c}0 \\
(0)\end{array}$ & $\begin{array}{c}22.616 * * * \\
D f=3\end{array}$ \\
\hline $\begin{array}{l}\text { Control } \\
n=30(\%)\end{array}$ & $\begin{array}{c}2 \\
(6.7)\end{array}$ & $\begin{array}{c}3 \\
(10)\end{array}$ & $\begin{array}{c}11 \\
(36.7)\end{array}$ & $\begin{array}{c}14 \\
(46.7)\end{array}$ & $\begin{array}{c}3 \\
(10)\end{array}$ & $\begin{array}{c}3 \\
(10)\end{array}$ & $\begin{array}{c}12 \\
(40)\end{array}$ & $\begin{array}{c}12 \\
(40)\end{array}$ & $\begin{array}{c}0.318^{N S} \\
D f=3\end{array}$ \\
\hline
\end{tabular}

$* * *$ Significant $\mathrm{p}<0.001$

experimental and control group respectively. In residence-wise distribution in the experimental group, that majority of elderly 22(73.3\%) were in the rural area and in control group majority of elderly $17(56.7 \%)$ were in the urban area. In religion, wise distribution in experimental group, that majority of elderly $23(76.7 \%)$ were belonged to Sikh in experimental group and in control group.

In educational status wise distribution in experimental group, majority of elderly 15 (50\%) and $12(40 \%)$ were illiterate, in experimental and control group respectively. In respect to marital status majority of elderly in experimental group $12(40 \%)$ were married and in control group majority of elderly 16(53.3\%) were widow/widower,

In occupation before joined to old age home, wise distribution majority of elderly in experimental group 14(46.7\%) were farmer/labourer, whereas in control group majority of them 13(43.3\%) were house wife. In accordance with source of income, in experimental group majority of elderly $14(46.7 \%)$ having no income and in control group, 16(53.3\%) were got support from family/others.

In relation to reason for staying in old age home in experimental group and control group majority of elderly $23(76.7 \%)$ and $14(46.7 \%)$ were neglected from children/family respectively. In accordance with length of stay in old age home in experimental group and control group majority of them $21(70 \%)$ and $13(43.3 \%)$ were up to 2 years respectively

Table also depicts that there is a significant difference among residence, the source of income and reason for staying in old age home between experimental and control group at baseline. Other variables like age, gender, religion, educational status, marital status, occupation before joined to old age home and length of stay in old age home are significant similar at baseline.

Table 2 shows the pre-test, post test level of anxiety, chi-square values with degree of freedom in the pre-test and post test of experimental group and control group. In comparison of pre-test and post test level of anxiety within experimental group ( $\boldsymbol{x} \mathbf{2}=\mathbf{2 2} . \mathbf{6 1 6}$ at $\mathbf{d f}=\mathbf{3})$, it shows significance at 0.05 the level of significance. Whereas in comparison of pre-test and post test level of anxiety within control group $(\boldsymbol{\varkappa} \mathbf{2}=\mathbf{0 . 3 1 8}$ at $\mathbf{d f}=\mathbf{3})$ it shows non-significance at 0.05 the level of significance. It shows significance at 0.05 the level of significance.

In the association of pre-test level of anxiety with the selected demographic variables (Table 3 ) in both experimental group and control group. In this there was a significant association of pre-test level of anxiety with gender statistically analyzed by a chi-square (0.580) at 0.05 level of significance.

But there is no significant association of pretest level of anxiety with age, residence, religion, educational status, marital status, occupation before joining to old age home, source of income, reason for staying in old age home and length of stay in old age home.

\section{DISCUSSION}

The findings of the study were discussed according to the objectives which were stated. The present study supported by these research findings. Lisa Sam( 2014) ${ }^{9}$ conducted a quasiexperimental study to determine the effectiveness of progressive muscle relaxation technique on anxiety. The mean level of anxiety during pre-test was 89.8 and during post-test it was reduced to 69.5. After STP, the anxiety level was reduced from moderate to a mild level. There was an effectiveness found after structured teaching program of progressive muscle relaxation 
Table 3. Association of pre-test level of anxiety with selected demographic variables $(n=60)$

\begin{tabular}{|c|c|c|c|c|c|c|c|}
\hline \multirow{2}{*}{$\begin{array}{l}\text { S.R } \\
\text { No. }\end{array}$} & \multirow[t]{2}{*}{ DEMOGRAPHIC VARIABLES } & \multicolumn{4}{|c|}{ ANXIETY LEVEL CATEGORY } & \multirow{2}{*}{$\begin{array}{c}\text { chi-square } \\
\text { value/ } \\
\text { Df }\end{array}$} & \multirow[t]{2}{*}{ p-value } \\
\hline & & $\begin{array}{c}\text { No } \\
\text { anxiety }\end{array}$ & $\begin{array}{c}\text { Mild } \\
\text { anxiety }\end{array}$ & $\begin{array}{c}\text { Moderate } \\
\text { anxiety }\end{array}$ & $\begin{array}{l}\text { Severe } \\
\text { anxiety }\end{array}$ & & \\
\hline
\end{tabular}

1. Age (in years)

a) $60-65$

b) $66-70$

$2 \quad 2$

$\begin{array}{cc}7 & 7 \\ 8 & 13 \\ 5 & 5 \\ 5 & 2\end{array}$

2. Gender:

c) $71-75$

d) $>75$

$0 \quad 1$

7

$\begin{array}{lllllll}\text { a) Male } & 2 & 3 & 15 & 17 & 0.580 & 0.901^{* *} \\ \text { b) Female } & 2 & 1 & 10 & 10 & \text { Df }=3 & \end{array}$

3. Residence :
a) Rural

b) Urban

$\begin{array}{lccccc}1 & 2 & 16 & 17 & 2.47 & 0.480^{\mathrm{NS}} \\ 3 & 2 & 9 & 10 & \mathrm{Df}=3 & \end{array}$

4. Religion:
a) Sikh
b) Hindu
c) Muslim
d) Any other

5. Educational status:

$\begin{array}{lllcccc}\text { a) Illiterate } & 3 & 1 & 12 & 12 & 12.1 & 0.209^{\text {NS }} \\ \text { b) Below middle } & 1 & 1 & 10 & 6 & \text { Df=9 } & \\ \text { c) Below senior secondary } & 0 & 1 & 3 & 8 & & \\ \text { d) Graduate } & 0 & 1 & 0 & 1 & \end{array}$

6. Marital status:

$\begin{array}{llccccc}\text { a) Single } & 2 & 1 & 8 & 5 & & \\ \text { b) Married } & 0 & 1 & 5 & 10 & 4.77 & 0.854^{\text {NS }} \\ \text { c) Widow/ widower } & 2 & 2 & 11 & 11 & \text { Df }=9 & \\ \text { d) Divorced } & 0 & 0 & 1 & 1 & & \end{array}$

7. Occupation before joined to old age home

$\begin{array}{lllcccc}\text { a) Government employee } & 0 & 0 & 1 & 2 & 6.77 & \\ \text { b) Private employee } & 1 & 0 & 5 & 3 & \text { Df }=9 & 0.661^{\mathrm{NS}} \\ \text { c) House wife } & 3 & 2 & 9 & 8 & & \\ \text { d) Any other: farmer/laborer } & 0 & 2 & 10 & 14 & & \end{array}$

8. Source of income

$\begin{array}{lllcccc}\text { a) Pensioner } & 1 & 0 & 10 & 7 & 8.71 & 0.190^{\mathrm{NS}} \\ \text { b) Support from family/ others } & 3 & 3 & 7 & 8 & \mathrm{Df}=6 & \\ \text { c) None } & 0 & 1 & 8 & 12 & & \end{array}$

9. Reason for staying in old age home

$\begin{array}{llllll}\text { a) No family members/ } & 1 & 1 & 10 & 5 & \\ \begin{array}{l}\text { relatives } \\ \text { beglected from children }\end{array} & 3 & 2 & 14 & 18 & \begin{array}{r}5.415 \\ \text { Df }=6\end{array} \\ \begin{array}{l}\text { /family } \\ \text { c) Poverty }\end{array} & 0 & 1 & 1 & 4 & \\ \text { d) Any other reason } & 0 & 0 & 0 & 0 & \end{array}$

10. Length of stay in old age home

\begin{tabular}{lllcccc} 
a) Up to 2 years & 0 & 2 & 13 & 19 & 7.92 & $0.244^{\mathrm{NS}}$ \\
b) 2- 5years & 2 & 1 & 7 & 5 & $\mathrm{Df}=6$ & \\
c) More than 5 years & 2 & 1 & 5 & 3 & & \\
\hline
\end{tabular}

*S- significant at 0.05 level of significance, NS - non-significant

technique. Sheetal Barde $\left(\right.$ 2013) ${ }^{10}$ conducted an experimental study to assess the effectiveness of progressive muscle relaxation technique on generalized anxiety of elderly Results shows in pre- 
intervention the mean average, maximum anxiety in control group was 74 and in experimental group it was 85 , whereas in post intervention, in control group the mean average of anxiety was 65.2 and 46.7 in experimental group. Finding indicated that the Jacobson Progressive muscle relaxation technique was effective for anxiety reduction among elderly orthopaedic patients.

The present study showed significant association of level of anxiety with the educational status and length of stay in old age home with pretest level of anxiety in the experimental group at 0.05 level of significance. Kirmizioglu et al ${ }^{11}$ conducted a study to compare the possible relationship between levels of anxiety among active and sedentary elderly. Results showed significant association of level of anxiety with educational status.

Zehra Outrank et. al ${ }^{12}$ conducted a study to find out the level of anxiety evaluate its relationship with several socio-demographic and clinical variables among elderly The results of this study presented the significant relationship between anxiety and education and number of children among elderly patients at 0.05 level of significance.

\section{IMPLICATIONS AND RECOMMENDATIONS}

Progressive muscle relaxation technique needs to be implemented as a part of other therapies and to be practiced by the nurse in day to day activities. Findings of the study will act as a catalyst to carry out more extensive research in a large sample and in other settings, and such research work enforces evidence-based practice. The study recommends that progressive muscle relaxation technique should be given for more than seven days, and study should be conducted on a large sample. Non-pharmacological anxiety management should be emphasized in nursing curriculum. Training programs to nurses can be given on complementary therapies.

\section{CONCLUSIONS}

Most of the study subjects experienced moderate to severe level of anxiety. Then Progressive muscle relaxation technique was demonstrated to participants in the experimental group and intervention continued for seven days. Hence, it concluded that Progressive muscle relaxation technique was effective in reducing the level of anxiety among elderly.

\section{LIMITATIONS}

The study is limited to selected old age homes of Punjab.
Conflict of Interest: None

Source of Funding: Self

Acknowledgement : Participants

\section{REFERENCES}

1. Pandya R, Shukla B. Elderly and their recreational needs. Journal of Social Welfare. 2011 Oct; 58(7): 24.

2. Townsend M C. Psychiatric Mental Health Nursing. $7^{\text {th }}$ edi (Indian). New Delhi: Jaypee brothers publisher. 2012: p 833.

3. Schoevers RA, Beekman ATF, Deeg DJH, Jonker C, Tilburg $\mathrm{W}$ van. Comorbidity and risk-patterns of depression, generalised anxiety disorder and mixed anxiety-depression in later life: results from the AMSTEL study. International Journal of Geriatric Psychiatry. 2003;18(11):994-1001. Available from: http://dx.doi.org/10.1002/gps.1001.

4. Lenze. More older adults affected by anxiety disorder than depression. [cited on Oct, 2014) Retrieved from: http://www.webmd.com/anxietypanic/guide/20060522/anxiety- missed-elderly.

5. Census of India, 2011. [Accessed in 2014]. Available from: http://www.censusindia.net

6. National health census 2001. Elderly census.[online]. (cited on April 15th 2014); Available from www.healthorg.com

7. Karrie J. Craig, Kelly J. Brown, and Andrew Baum. Environmental Factors in the Etiology of Anxiety, 2000 (online) [ cited 2014, December] Available from http://www.acnp.org/g4/GN401000127/CH125.ht $\mathrm{ml}$

8. Tiwari S, Pandey N. Status and requirements of geriatric mental health services in India: An evidence-based commentary. Indian J Psychiatry. 2012;54(1):8. Available from: http://dx.doi.org/10.4103/0019-5545.94639.

9. Ms. Lisa Sam. Effectiveness of progressive muscle relaxation technique on anxiety Sinhgad e Journal of Nursing.(online) 2014 june;4(1).

10. Barde S. Effectiveness of Progressive Muscle Relaxation Technique on Generalized Anxiety of Elderly Orthopaedic Patients in selected Hospitals, of Pune City. The Journal of Psychiatric Nursing.2013: 2(2):59-62.

11. Minghelli B, et al.Comparison of levels of anxiety and depression among active and sedentary elderly. [cited on: December,2014] Available from : http://www.hcnet.usp.br/ipq/revista/vol40/n2/eng /71.htm 
International Journal of Therapeutic Applications, Volume 32, 2016, 48-54

12. Yalcın Kirmizioglu, Orhan Dogan' ,Nesim Kugu and Gamze Akyuz. Prevalence of anxiety disorders among elderly. International Journal of Geriatric Psychiatry. 2009: 24(9) 1026-33.

13. Kirmizioglu $Y$, Doğan $O$, Kuğu N, Akyüz G. Prevalence of anxiety disorders among elderly people. International Journal of Geriatric Psychiatry. 2009 Sep;24(9):1026-33. Available from: http://dx.doi.org/10.1002/gps.2215. 